\title{
PReS-FINAL-2018: The P53 gene polymorphisms and juvenile idiopathic arthritis
}

\author{
A Kozhevnikov ${ }^{1,2^{*}}$, N Pozdeeva ${ }^{2}$, M Konev $^{2}$, M Nikitin $^{3}$, V Larionova ${ }^{2}$, G Novik$^{1}$, M Slyndev $^{3}$ \\ From 20th Pediatric Rheumatology European Society (PReS) Congress \\ Ljubljana, Slovenia. 25-29 September 2013
}

\section{Introduction}

Juvenile idiopathic arthritis (JIA) is a multifactor chronic inflammatory joints disease that is characterized by long progressive course leading to the development of contractures and loss of joint function. Prediction of the likely outcomes and course of JIA is key approach of treatment. Currently, there are only several laboratory and radiological predictors of unfavorable prognosis of JIA. Reduced sensitivity of cells to apoptosis is one the possible mechanisms maintaining synovial inflammation in JIA. Polymorphisms Arg72Pro 4exon, ins/dell6bp 3intron, G/C 6intron can determine activity of the P53 protein - the key protein of intrinsic apoptosis pathway (P.Dumont et al 2003; A.Sallivan et al, A.Ghosh et al 2004).

\section{Objectives}

We evaluated role of P53 gene polymorphisms in the course and outcome of JIA.

\section{Methods}

Clinical, serological, $x$-ray manifestations, ultrasound and MRI were analyzed in 126 children with JIA. 60 healthy children without family history of any autoimmune disease were controls. The P53 gene polymorphisms were detected by PCR-RFLP.

\section{Results}

We haven't revealed significant differences in genotypes distributions of Arg72Pro ex4, ins/del16bp in3 and G/C in6 between children with JIA and controls. We identified significant difference of exon genotype Arg72Pro in girls who still persistently in «active disease» more 2 years compared with girls who achieved clinical remission (Arg/Arg - $36,7 \%$ vs $83,3 \%$, Arg/Pro - $51,1 \%$ vs $16,7 \%$,
Pro/Pro - $12,2 \%$ vs $0 \%) .68 \%$ girls who achieved «inactive» oligoarthicular (OA) and polyarthicular (PA) were with homozygous genotype Arg/Arg. Girls with Pro allele genotypes (Arg/Pro, Pro/Pro) have the highest rates of probability of the «active disease $\gg$ for OA $(\mathrm{OR}=$ $158,3, \mathrm{p}=0,0001)$ and PA (OR $=32,8, \mathrm{p}=0,005)$ compared with ERA (OR $=0,5, \mathrm{p}=0,8)$. Boys haven't any difference of exon genotype in JIA ( $p>0,05$, OR $<2,5)$. We received no information about influence of intronic polymorphisms on the JIA course. We haven't any difference of polymorphisms P53 gene in children with joints erosion and arthrosis.

Haplotypes */del-Arg/Arg-GG were significantly higher in girls with clinical remission. Girls who still maintain an «active» OA and PA course had haplotypes */del-Arg/ Pro-G*, ins/del-Pro/Pro-GC, ins/ins-Pro/Pro-CC. Most girls with ins/del-Pro/Pro-GC, ins/ins-Pro/Pro-CC were with fibrous ankylosis.

\section{Conclusion}

We suggest that Pro allele genotypes of the exon polymorphism P53 gene contribute to persistence of «active disease» in girls with oligo-, polyarthritis. Analysis Arg72Pro 4exon, ins/del16bp 3intron, G/C 6intron polymorphisms $P 53$ gene can be used in a comprehensive assessment unfavorable risk of $J I A$ course in girls.

\section{Disclosure of interest}

None declared.

\footnotetext{
Authors' details

${ }^{1}$ Saint-Petersburg State Pediatric Medical University, Russian Federation. ${ }^{2}$ Hospital Department of Orthopedics and Rheumatology, Saint-Petersburg Research Pediatric Orthopedic Institute n. a. G.I. Turner, Russian Federation. "'Lumex Itd", Saint-Petersburg, Russian Federation.
} 
- Convenient online submission

- Thorough peer review

- No space constraints or color figure charges

- Immediate publication on acceptance

- Inclusion in PubMed, CAS, Scopus and Google Scholar

- Research which is freely available for redistribution 